\title{
Model Generalized Space Time Autoregressive (GSTAR) Orde 1 dan Penerapannya pada Prediksi Harga Beras di Kota Bitung, Kabupaten Minahasa dan Kabupaten Minahasa Selatan
}

\author{
${ }^{1}$ Youla M. A. Latupeirissa, ${ }^{2}$ Nelson Naingggolan, ${ }^{3}$ Tohap Manurung \\ 1'Jurusan Matematika, FMIPA, UNSRAT Manado, youlalatupeirissa@ yahoo.co.id \\ ${ }^{2}$ Jurusan Mate matika, FMIPA, UNSRAT, Manado, bapaivana@yahoo.co.id \\ 3 Jurusan Matematika, FMIPA, UNSRAT, Manado, kris_ton79@gmail.com
}

\begin{abstract}
This research describe Generalized Space Time Autoregressive (GSTAR) Order 1 model of rice price in Bitung city, Minahasa regency and South Minahasa regency specifically Superwin rice and Sultan rice, and rice price prediction in October, November and December 2013. Data that used was monthly price rice data from January 2008 to September 2013. Parameter estimation result for Superwin rice obtained parameter estimation value 0,007;0,348;0,211 and 0,503;0,021;0,244 and for Sultan rice obtained parameter estimation value 0,326; 0,475; 0,149 and 0,081;-0,078; 0,403. Data analysis result show that error was normally distribute. Prediction results for October, November and December 2013 in Bitung city for Superwin rice were Rp. 8.629, Rp. 8.500 and Rp. 8.500 and Sultan rice were Rp. 8.185, Rp. 8.000 and Rp. 8.000. For Minahasa regency, prediction result for October, November and December 2013 for Superwin rice were Rp. 8.810, Rp. 8.800 and Rp. 8.800 and Sultan rice were Rp. 8.761, Rp.8.800 and Rp. 8.800. For South Minahasa regency, prediction result for October, November and December 2013 for Superwin rice were Rp. 9.166, Rp. 9.000 and Rp. 9.000 and Sultan rice were Rp. 8.675, Rp. 8.500 and $R p .8 .500$.
\end{abstract}

Keywords: rice, space time, GSTAR order 1 model

\begin{abstract}
Abstrak
Penelitian ini membahas model Generalized Space Time Autoregressive (GSTAR) Orde 1 dari data harga beras di Kota Bitung, Kabupaten Minahasa dan Kabupaten Minahasa Selatan yang terdiri dari beras Superwin dan Sultan serta prediksi untuk harga beras di bulan Oktober, November dan Desember tahun 2013. Data yang digunakan adalah data harga bulanan beras periode Januari 2008 sampai September 2013. Hasil penaksiran parameter untuk beras Superwin diperoleh nilai taksiran parameter 0,$007 ; 0,348 ; 0,211$ dan 0,503 ; 0,$021 ; 0,244$ sedangkan untuk beras Sultan diperoleh nilai taksiran parameter 0,$326 ; 0,475 ; 0,149$ dan 0,$081 ;-$ 0,078; 0,403. Hasil prediksi yang diperoleh untuk periode bulan Oktober, November dan Desember tahun 2013 di Kota Bitung dengan jenis beras Superwin adalah Rp. 8.629, Rp. 8.500 dan Rp. 8.500 dan untuk jenis Sultan adalah Rp. 8.185, Rp. 8.000 dan Rp. 8.000. Untuk Kabupaten Minahasa prediks i yang diperoleh untuk periode bulan Oktober, November dan Desember tahun 2013 dengan jenis beras Superwin adalah Rp. 8.810, Rp. 8.800 dan Rp. 8.800 dan jenis Sultan adalah Rp. 8.761, Rp.8.800 dan Rp. 8.800. Untuk Kabupaten Minahasa Selatan hasil prediksi yang diperoleh untuk periode bulan Oktober, November dan Desember tahun 2013 dengan jenis beras Superwin adalah Rp. 9.166, Rp. 9.000 dan Rp. 9.000 dan jenis Sultan Rp. 8.675, Rp. 8.500 dan Rp. 8.500.
\end{abstract}

Kata kunci: beras, space time, model GSTA R orde 1

\section{Pendahuluan}

Salah satu komoditi pangan yang merupakan kebutuhan pokok dalam kehidupan masyarakat adalah beras. Beras sangat penting untuk menunjang pemenuhan gizi yang diperlukan tubuh karena beras merupakan sumber kalori yang utama dalam makanan. Beras merupakan bahan pokok yang sampai saat ini masih di konsumsi oleh sekitar 90\% penduduk Indonesia dan menyumbang lebih dari 50\% kebutuhan kalori serta hampir 50\% kebutuhan protein [1]. Sulawesi Utara pada umumnya terdapat berbagai jenis-jenis beras mulai dari beras jenis premium, medium, hingga yang berkualitas rendah. Harga beras yang cenderung meningkat setiap tahunnya terjadi karena kurangnya pasokan beras sementara permintaan beras di pasaran meningkat [11]. Harga beras erat kaitannya dengan peningkatan pendapatan dan kesejahteraan petani dan merupakan salah satu elemen penting dalam ekonomi pangan. Analisis harga beras menjadi hal penting dalam peningkatan produksi beras. 
Peramalan yang tepat dari suatu data produksi di waktu-waktu yang akan datang merupakan salah satu dasar utama perencanaan produksi. Data harga bulanan beras merupakan data time series. Dengan mempelajari data sebelumnya, harga beras pada masa yang akan datang dapat diprediksi. Dalam ilmu statistika, salah satu cara untuk memprediksi digunakan model time series. Dalam kehidupan sehari-hari seringkali dijumpai data yang tidak hanya mengandung keterkaitan dengan kejadian pada waktu-waktu sebelumnya, tetapi juga mempunyai keterkaitan dengan lokasi atau tempat yang lain yang disebut dengan data spasial[7].

Data harga bulanan beras tiap-tiap daerah dapat dimodelkan dalam model spasial dan model ruang-waktu (spac- time). Model space-time yang dikembangkan oleh Pfeifer dan Deutsch [6] adalah salah satu model yang menggabungkan unsur waktu dan lokasi pada data deret waktu dan lokasi. Model space-time ini mempunyai kelemahan pada fleksibilitas parameter yang menjelaskan keterkaitan lokasi dan waktu yang berbeda pada suatu data deret waktu dan lokasi. Kelemahan ini di perbaiki oleh Borovkova dan kawan-kawan (2002) [2] melalui suatu model yang dikenal dengan model Generalized Space Time Autoregressive (GSTAR). Model Generalized Space Time Autoregressive (GSTAR) adalah salah satu model yang banyak digunakan untuk memodelkan dan meramalkan data deret waktu dan lokasi, dimana model GSTAR menghasilkan model ruang-waktu (space-time) dengan parameter-parameter yang tidak harus sama untuk faktor waktu maupun lokasi. Model ini adalah pengembangan dari model Space Time Autoregressive (STAR) yang diperkenalkan pertama kali oleh Pfeifer dan Deutsch tahun 1980 [6].

\section{Model Generalized Space Time Autoregressive (GSTAR)}

Model Space Time Autoregressive (GSTAR) adalah salah satu pendekatan utama untuk menyelesaikan data deret waktu dan lokasi dengan menggabungkan faktor waktu dan lokasi pada suatu data deret waktu multivariate.

Model Generalized Space Time Autoregressive (GSTAR) adalah salah satu bentuk khusus dari model Autoregresive (AR) dan model Vector Autoregressive (VAR) [2][8]. Model Autoregressive (AR) adalah model yang menyatakan bahwa nilai pengamatan sekarang tergantung pada nilai pengamatan pada waktu-waktu sebelumnya dari dirinya sendiri ditambah dengan white noise [5]. Proses Autoregressive orde- $p$ ditulis dengan $\operatorname{AR}(p)$ adalah berbentuk:

$Z_{t}=\phi_{1} Z_{t-1}+\phi_{2} Z_{t-2}+\ldots+\phi_{p} Z_{t-p}+\varepsilon_{t}$

dengan $\varepsilon_{t}$ iid $N\left(0, \sigma^{2}\right)$ dimana $\phi$ koefisien parameter autoregresif ke- $p, \varepsilon_{t}$ white noise dengan rataan nol dan variansi $\sigma^{2}$. Model Vector Autoregressive (VAR) adalah model vektor yang paling sederhana. Misalkan $Z_{t}$ adalah vektor time series stasioner lemah berdimensi m. Maka Model VAR Orde-1, $\operatorname{VAR}(1)$ adalah sebagai berikut :

$\left(I-\Phi_{1} B\right) Z_{t}=\varepsilon_{t}$

atau

$Z_{t}=\Phi_{1} Z_{t-1}+\varepsilon_{t}$

dengan $\varepsilon^{i i d_{\sim}} N(0, \Sigma)$, dimana $\Sigma$ matriks $m$ x $m$ simetri, definit positif. Untuk proses white noise diasumsikan : $\Sigma=\sigma^{2} \boldsymbol{I}_{m}$.

Model GSTAR menghasilkan model ruang waktu (space-time) dimana model ruang waktu ini mengadopsi tahapan-tahapan model Autoregressive Intergarated Moving Average (ARIMA) atau biasa disebut Box-Jenkins yang dikembangkan oleh George Box dan Gwilym Jenkins tahun 1976 [3][4]. Secara umum persamaan model ARIMA adalah:

$W_{t}=\phi_{1} W_{t-1}+\phi_{2} W_{t-2}+\ldots+\phi_{p} W_{t-p}+\varepsilon_{t}-\varepsilon_{t}-\theta_{1} \varepsilon_{t-1}-\ldots-\theta_{q} \varepsilon_{t-q}$

dimana:

$W_{t}=Z_{t}-Z_{t-1}$

sehingga,

$Z_{t}-Z_{t-1}=\phi_{1}\left(Z_{t-1}-Z_{t-2}\right)+\phi_{2}\left(Z_{t-2}-Z_{t-3}\right)+\ldots+\phi_{p}\left(Z_{t-p}-Z_{t-p-1}\right)$

$+\varepsilon_{t}-\theta_{1} \varepsilon_{t-1}-\ldots-\theta_{q} \varepsilon_{t-q}$

Model ARIMA adalah model time series yang tidak stasioner, oleh karena itu stasioneritas dari model GSTAR dapat diperoleh dari kestasioneran model VAR. Model GSTAR biasa digunakan pada lokasi 
dengan sifat heterogen dengan parameter-parameter yang tidak harus sama untuk faktor waktu maupun lokasi.

Dalam notasi matriks model yang umum GSTAR, misalnya orde $p$ dalam time dan orde $l=0,1$, $\ldots, \lambda_{k}$ dalam space dituliskan sebagai:

$Z(t)=\sum_{k=1}^{p} \sum_{l=0}^{\lambda_{k}} \phi_{k l} \boldsymbol{W}^{(t)} \boldsymbol{Z}(t-k)+\varepsilon(t)$

Penaksiran parameter model GSTAR dapat dilakukan dengan menggunakan metode kuadrat terkecil dengan cara meminimkan jumlah kuadrat simpangannya.

Jika jumlah pengamatan $Z_{i}(t), t=0,1, \ldots, T$ untuk lokasi $i=1,2, \ldots, n$

dengan $V_{i}(t)=\sum_{j-i}^{n} W_{i j} Z_{j}(t)$

Maka model untuk lokasi ke-i dapat ditulis sebagai berikut

$Y_{i}=X_{i} \beta_{i}+u_{i}$

dimana $\beta_{i}=\left(\phi_{0 i}+\phi_{1 i}\right)$

$Y_{i}=\left[\begin{array}{c}Z_{i}(1) \\ Z_{i}(2) \\ Z_{i}(3)\end{array}\right], X_{i}=\left[\begin{array}{cc}Z_{i}(0) & V_{i}(0) \\ Z_{i}(1) & V_{i}(1) \\ \vdots & \vdots \\ Z_{i}(T-1) & V_{i}(T-1)\end{array}\right]$

Pemilihan bobot lokasi adalah salah satu permasalahan utama dalam pemodelan GSTAR. Metode yang digunakan sebagai pembobot lokasi [9] dalam GSTAR salah satunya adalah bobot seragam. Pada pembobotan menggunakan metode ini setiap lokai dianggap homogen sehingga memiliki pembobot yang sama.

Matriks bobot seragam (W) dalam lag spasial 1 adalah berupa matriks bujur sangkar $(N \mathrm{x} N)$ yang dapat dituliskan dengan:

$W=\left[\begin{array}{cccc}0 & w_{12} & \ldots & w_{1 N} \\ w_{21} & 0 & \ldots & w_{2 N} \\ \vdots & \vdots & \vdots & \vdots \\ w_{N 1} & w_{N 2} & \ldots & 0\end{array}\right]$

Secara matematik bobot seragam lag spasial 1, didefinisikan sebagai:

$w_{\mathrm{i} j}=\left\{\begin{aligned} \frac{1}{n_{\mathrm{i}}^{(1)},} & i \text { dan } j \text { di lag spasial } 1 \\ 0, & \text { lainnya }\end{aligned}\right.$

Matriks bobot seragam yang digunakan, yaitu:

$\left(\begin{array}{ccc}0 & w_{12}{ }^{(1)} & w_{1 \mathrm{a}}{ }^{(1)} \\ w_{21}^{(\mathbb{1})} & 0 & w_{2 \mathrm{a}}{ }^{[1]} \\ w_{21}^{(1)} & w_{22}{ }^{(1)} & 0\end{array}\right)=\left(\begin{array}{ccc}0 & 1 / 2 & 1 / 2 \\ 1 / 2 & 0 & 1 / 2 \\ 1 / 2 & 1 / 2 & 0\end{array}\right)$

Untuk model GSTAR $(1,1)$ untuk 3 lokasi dapat ditulis kan:

$$
\begin{aligned}
\left(\begin{array}{l}
Z_{1}(t) \\
Z_{2}(t) \\
Z_{3}(t)
\end{array}\right) & =\left(\begin{array}{ccc}
\phi_{10}{ }^{(1)} & 0 & 0 \\
0 & \phi_{10}{ }^{(2)} & 0 \\
0 & 0 & \phi_{10}{ }^{(3)}
\end{array}\right)\left(\begin{array}{l}
Z_{1}(t-1) \\
Z_{2}(t-1) \\
Z_{3}(t-1)
\end{array}\right) \\
& +\left(\begin{array}{ccc}
\phi_{11}{ }^{(1)} & 0 & 0 \\
0 & \phi_{11}{ }^{(2)} & 0 \\
0 & 0 & \phi_{11}{ }^{(3)}
\end{array}\right)\left(\begin{array}{ccc}
0 & w_{12}{ }^{(1)} & w_{13}{ }^{(1)} \\
w_{21}{ }^{(1)} & 0 & w^{(1)} \\
w_{31}{ }^{(1)} & w_{32}{ }^{(1)} & 0
\end{array}\right)\left(\begin{array}{l}
z_{1}(t-1) \\
Z_{2}(t-1) \\
z_{3}(t-1)
\end{array}\right)+\left(\begin{array}{l}
e_{1}(t) \\
e_{2}(t) \\
e_{3}(t)
\end{array}\right)
\end{aligned}
$$

\section{Metode Penelitian}

Data yang digunakan dalam penelitian adalah data sekunder berupa data kuantitatif harga bulanan dari beras jenis Superwin dan Sultan di 3 lokasi yaitu Kota Bitung, Kabupaten Minahasa dan Kabupaten Minahasa Selatan dengan data harga beras sebanyak 69 data yaitu periode bulan Januari 2008 sampai dengan bulan September 2013. Data diperoleh dari Dinas Perindustrian dan Perdagangan (DISPERINDAG) di masing-masing Kabupaten/Kota. 
Dalam tahapan analisis data akan dilakukan dengan urutan sebagai berikut:

1. Identifikasi Model

Tahapan ini adalah menetukan model peramalan yang tampaknya cocok dengan data deret waktu yang dipe lajari. Dengan menggunakan plot ACF dan PACF maka dapat ditentukan model yang akan digunakan dalam prediksi.

2. Menentukan Matriks Bobot

Matriks bobot yang digunakan adalah matriks bobot seragam.

3. Menaksir Parameter

Metode yang digunakan untuk menaksir parameter adalah Metode Kuadrat Terkecil. Perhitungan penaksiran parameter menggunakan software S-Plus 8.0.

4. Uji Diagnostik

Uji diagnos is untuk melihat apakah galat (error) yang dihasilkan sudah berdistribusi normal dan layak untuk digunakan.

5. Prediksi Harga

Prediksi dilakukan untuk melihat gambaran harga beras untuk waktu mendatang.

Skema me tode analisis

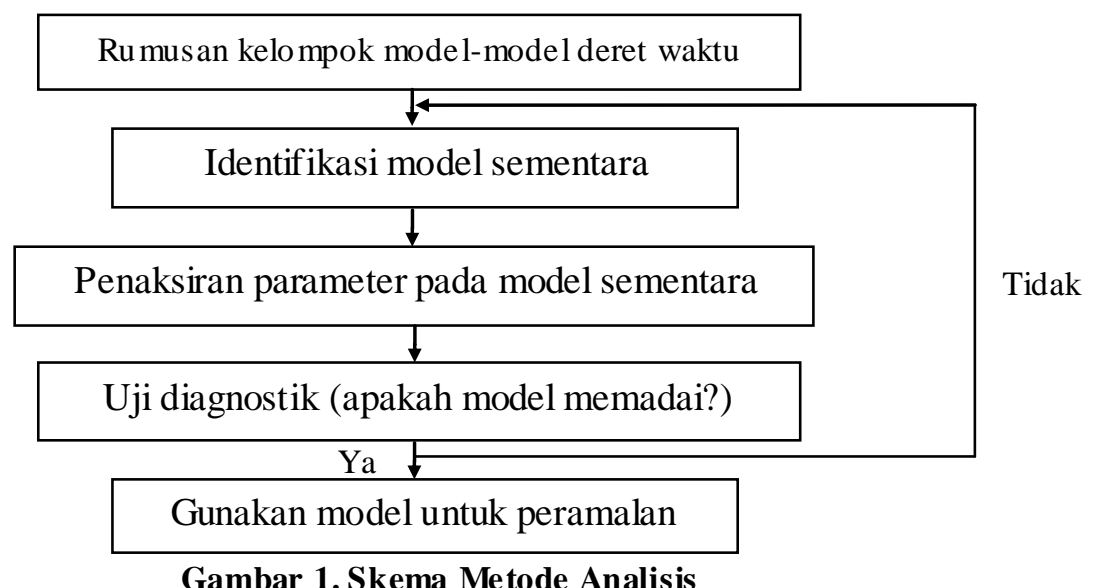

\section{Hasil dan Pembahasan}

\subsection{Harga Bulanan Beras Superwin dan Sultan Periode Bulan Januari 2008 sampai dengan September 2013}

Eksplorasi data harga bulanan beras superwin dan sultan periode bulan Januari 2008 sampai dengan September 2013 di Kota Bitung, Kabupaten Minahasa dan Kabupaten Minahasa Selatan sebanyak 69 data dapat dilihat pada Gambar 1 dan Gambar 2.

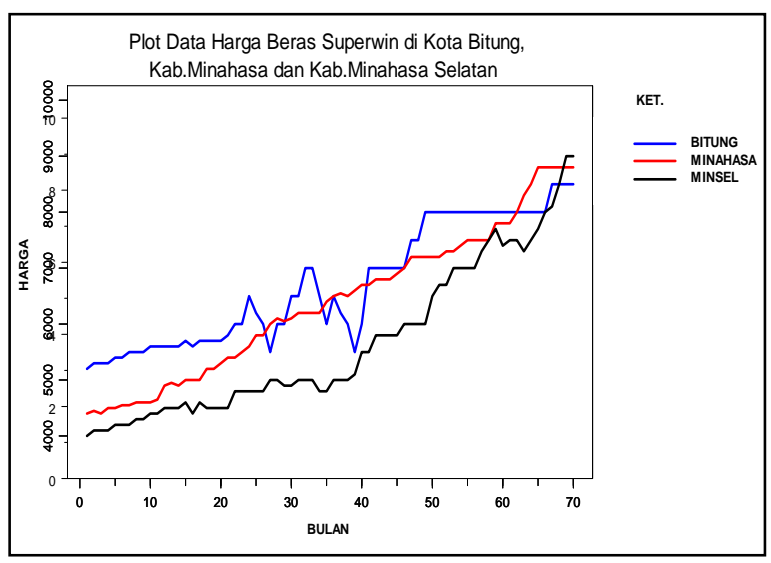

Gambar 2. Plot Data Harga Bulanan Superwin di Kota Bitung, Kabupaten Minahasa dan Kabupaten Minahasa Selatan

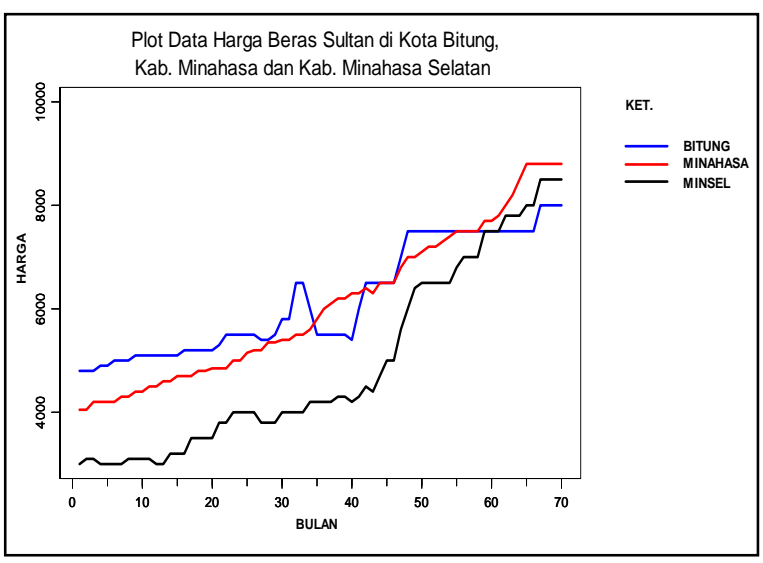

Gambar 3. Plot Data Harga Bulanan Sultan di Kota Bitung, Kabupaten Minahasa dan Kabupaten Minahasa Selatan 
Berdasarkan plot di atas menunjukkan bahwa grafik cenderung bergerak naik yang berarti data belum stasioner dalam rata-rata karena berubah seiring perubahan waktu. Melalui analis is ACF PACF dan proses selisih (differencing) untuk data harga beras ketiga lokasi dihasilkan data yang bersifat stasioner dan dapat dilanjutkan dengan penentuan parameter tiap jenis beras kemudian menentukan model GSTAR orde- 1 .

\subsection{Penentuan Model GSTAR Orde 1 Data Harga Bulanan Beras Superwin dan Sultan di Kota Bitung, Kabupaten Minahasa dan Kabupaten Minahasa Selatan}

Parameter ditentukan dengan Metode Kuadrat Terkecil (MKT), dimana nilai-nilai parameter dihitung menggunakan software S-Plus 8.0 Hasil penaksiran parameter untuk beras Superwin diperoleh nilai taksiran parameter $\phi_{10}=(0,007 ; 0,348 ; 0,211)$ dan $\phi_{11}=(0,503 ; 0,021 ; 0,244)$, sedangkan untuk beras Sultan diperoleh nilai taksiran parameter $\phi_{10}=(0,326 ; 0,475 ; 0,149)$ dan $\phi_{10}=(0,081 ;-0,078 ; 0,403)$. Model GSTAR orde-1 data harga beras superwin dan sultan untuk Kota Bitung, Kabupaten Minahasa dan Kabupaten Minahasa Selatan adalah sebagai berikut:

$$
\begin{aligned}
\left(\begin{array}{l}
\widehat{W}_{1}(t) \\
\widehat{W}_{2}(t) \\
\widehat{W}_{2}(t)
\end{array}\right) & =\left(\begin{array}{ccc}
0.007 & 0 & 0 \\
0 & 0.384 & 0 \\
0 & 0 & 0.211
\end{array}\right)\left(\begin{array}{l}
W_{1}(t-1) \\
W_{2}(t-1) \\
W_{3}(t-1)
\end{array}\right) \\
& +\left(\begin{array}{ccc}
0.503 & 0 & 0 \\
0 & 0.021 & 0 \\
0 & 0 & 0.244
\end{array}\right)\left(\begin{array}{ccc}
0 & 0.5 & 0.5 \\
0.5 & 0 & 0.5 \\
0.5 & 0.5 & 0
\end{array}\right)\left(\begin{array}{l}
W_{1}(t-1) \\
W_{2}(t-1) \\
W_{3}(t-1)
\end{array}\right)
\end{aligned}
$$

Persamaan 9 kemudian disederhanakan menjadi:

$\left(\begin{array}{l}W_{1}(t) \\ \widehat{W}_{2}(t) \\ \widehat{W}_{3}(t)\end{array}\right)=\left(\begin{array}{l}0.007 W_{1}(t-1) \\ 0.384 W_{2}(t-1) \\ 0.211 W_{3}(t-1)\end{array}\right)+\left(\begin{array}{ccc}0 & 0.2515 & 0.2515 \\ 0.0105 & 0 & 0.0105 \\ 0.122 & 0.122 & 0\end{array}\right)\left(\begin{array}{l}W_{1}(t-1) \\ W_{2}(t-1) \\ W_{3}(t-1)\end{array}\right)$

Dari persamaan 10 dapat dituliskan model sementara GSTAR Orde-1 untuk prediksi harga beras superwin di tiga lokasi sebagai berikut:

1. Model GSTAR Data Harga Beras Superwin di 3 Lokasi :

$Z_{1}(t)=1.007 Z_{1}(t-1)-0.007 Z_{1}(t-2)+0.2515\left(Z_{2}(t-1)-Z_{2}(t-2)\right)$

$$
\begin{aligned}
& +0.2515\left(Z_{3}(t-1)-Z_{3}(t-2)\right) \\
Z_{2}(t)= & 1.384 Z_{2}(t-1)-0.384 Z_{2}(t-2)+0.0105\left(Z_{1}(t-1)-Z_{1}(t-2)\right) \\
& +0.0105\left(Z_{3}(t-1)-Z_{3}(t-2)\right) \\
Z_{3}(t)= & 1.211 Z_{3}(t-1)-0.211 Z_{3}(t-2)+0.122\left(Z_{1}(t-1)-Z_{1}(t-2)\right) \\
& +0.122\left(Z_{2}(t-1)-Z_{2}(t-2)\right)
\end{aligned}
$$

2. Model GSTAR Data Harga Beras Sultan di 3 Lokasi :

$$
\begin{aligned}
Z_{1}(t)= & 1.326 Z_{1}(t-1)-0.326 Z_{1}(t-2)+0.045\left(Z_{2}(t-1)-Z_{2}(t-2)\right) \\
& +0.045\left(Z_{3}(t-1)-Z_{3}(t-2)\right) \\
Z_{2}(t)= & 1.475 Z_{2}(t-1)-0.475 Z_{2}(t-2)-0.039\left(Z_{1}(t-1)-Z_{1}(t-2)\right) \\
& \left.-0.039(t-1)-Z_{3}(t-2)\right) \\
Z_{3}(t)= & 1.149 Z_{3}(t-1)-0.149 Z_{3}(t-2)+0.2015\left(Z_{1}(t-1)-Z_{1}(t-2)\right) \\
& +0.2015\left(Z_{2}(t-1)-Z_{2}(t-2)\right)
\end{aligned}
$$




\subsection{Prediksi Data Harga Bulanan Beras Superwin dan Sultan Pada Bulan Oktober 2013 sampai dengan Desember 2013}

Perbandingan hasil prediksi beras superwin dan sultan dengan data sebenarnya di tunjukkan pada gambar 3 dan gambart 4 berikut:

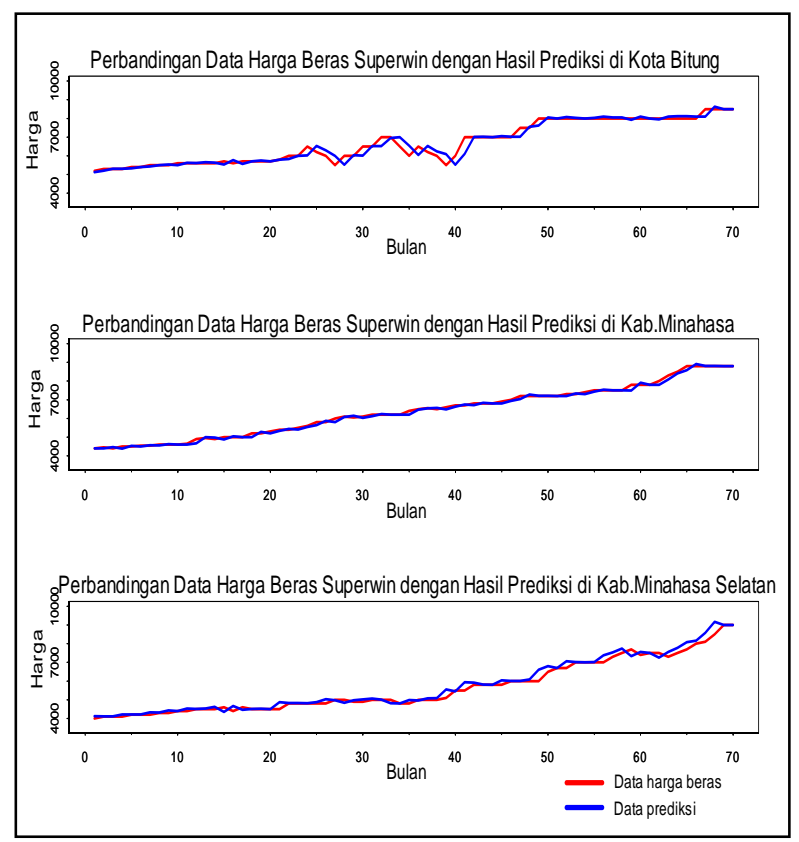

Gambar 4. Perbandingan Data Harga Bulanan Superwin di Kota Bitung, Kabupaten Minahasa dan Kabupaten Minahasa Selatan dengan Hasil Prediksi

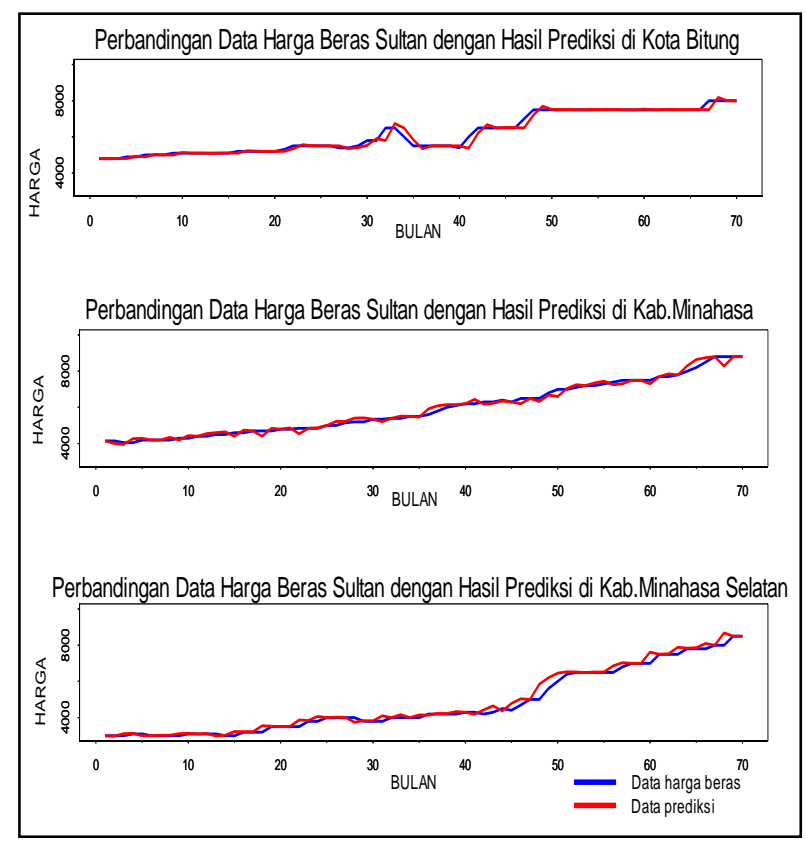

Gambar 5. Perbandingan Data Harga Bulanan Sultan di Kota Bitung, Kabupaten Minahasa dan Kabupaten Minahasa Selatan dengan Hasil Prediksi

Dari gambar 3 dan gambar 4 dapat diketahui bahwa hasil perbandingan antara data harga beras superwin yang sebenarnya untuk tiga lokasi tidak berbeda jauh dengan data harga beras superwin hasil prediks i.Melalui hasil perhitungan, analisis grafik serta model peramalan yang ada, maka dapat diketahui bahwa hasil prediksi harga bulanan beras jenis Superwin pada bulan Oktober sampai dengan bulan Desember 2013 adalah seperti tabel 1 dan tabel 2.

Tabel 1. Pre diksi Data Harga Superwin di 3 Lokasi

\begin{tabular}{|c|c|c|c|}
\hline Bulan/Tahun & Bitung & Minahasa & Minse1 \\
\hline Oktober 2013 & 8629 & 8810 & 9166 \\
\hline November 2013 & 8500 & 8800 & 9000 \\
\hline Desember 2013 & 8500 & 8800 & 9000 \\
\hline
\end{tabular}

Tabel 2. Prediksi Data Harga Sultan di 3 Lokasi

\begin{tabular}{|c|c|c|c|}
\hline Bulan/Tahun & Bitung & Minahasa & Minse 1 \\
\hline Oktober 2013 & 8185 & 8761 & 8675 \\
\hline November 2013 & 8000 & 8800 & 8500 \\
\hline Desember 2013 & 8000 & 8800 & 8500 \\
\hline
\end{tabular}




\section{Kesimpulan}

Hasil Prediksi harga beras superwin di Kota Bitung bulan Oktober 2013 adalah Rp. 8.629 November 2013 adalah Rp.8.500 dan Desember 2013 adalah Rp.8.500. Prediksi untuk harga beras superwin di Kabupaten Minahasa bulan Oktober 2013 adalah Rp.8.810, bulan November 2013 adalah Rp.8.800 dan bulan Desember adalah Rp.8.800. Selanjutnya prediksi untuk harga beras superwin di Kabupaten Minahasa Selatan bulan Oktober 2013 adalah Rp.9.166, bulan November 2013 adalah Rp.9.000 dan bulan Desember adalah Rp.9.000.Hasil Prediksi harga beras sultan di Kota Bitung bulan Oktober 2013 adalah Rp. 8.185, bulan November 2013 adalah Rp.8.000 dan bulan Desember 2013 adalah Rp.8.000. Prediksi untuk harga beras sultan di Kabupaten Minahasa bulan Oktober 2013 adalah Rp.8.761, bulan November 2013 adalah Rp.8.800 dan bulan Desember adalah Rp.8.800. Selanjutnya prediksi untuk harga beras sultan di Kabupaten Minahasa Selatan bulan Oktober 2013 adalah Rp.8.675.25, bulan November 2013 adalah Rp.8.500 dan Bulan Desember adalah Rp.8.500.

\section{Daftar Pustaka}

[1] Amang, B. 1995. Pembangunan Pertanian dan Perdagangan Komoditi Pertanian di Kawasan Timur Indonesia. Penerbit Dharma Karsa Utama. Jakarta

[2] Borovkova, S.A., dkk. 2008. Consistency and Asymptotic Normality of Least Square Estimators in Generalized STAR Models. Journal Compilation Statistica Neerlandica, Neerlandica, Vol. 62(4), pp. 482508

[3] Box, G.E.P., and Jenkins, G.M. 1976. Time Series Anysis: Forecasting and Control. Rev Edition. HoldenDay Inc. San Fransisco

[4] Irawan, N dan Astuti, P.S. 2006. Mengolah Data Statistik dengan Mudah Menggunakan Minitab 14. Penerbit Andi. Yogyakarta

[5] Nainggolan, N. 2011. Pengembangan Model GSTAR dengan Galat ARCH dan Penerapannya pada Inflasi. [disertasi] UNPAD, Bandung.

[6] Pfeifer, P.E., and Deutsch, S.J. 1980. A Three-Stage Iterative Procedure for Space Time Modeling. School of Industrial and System Engineering Georgia Institute of Technology Atlanta. Technometrics, 22 (1), pp. 34-47

[7] Prisandy D. E. 2008. Penerapan Metode GSTAR $\left(P_{1}\right)$ untuk Meramalkan Data Penjualan Rokok di Tiga Lokasi. Jurnal Ilmiah Widya Teknik, Vol. 7 (2), pp. 199-210

[8] Ruchjana, B.N. 2002. Pemodelan Kurva Produksi Minyak Bumi Menggunakan Model Generalisasi STAR. Forum Statistika dan Komputasi, IPB, Bogor

[9] Suhartono dan Subandar. (2006). The Optimal Determination of Space Wight in GSTAR Model by Using Cross-Correlation Inference, JOURNAL OF QUANTITATIVE METHODS: Journal the Mathematical and Statistical Application in Various Field, Vol. 2 (2), pp. 45-53

[10] Supranto, J. M.A. 1984. Meode Ramalan Kuantitatif untuk Perencanaan (edisi kedua). Penerbit PT Gramedia. Jakarta

[11] Wuwung, V. 2012. Prediksi Harga Beras Sultan dan Sultan di Kota Manado dengan Menggunakan Model ARIMA [skripsi]. FMIPA UNSRAT. Manado. 